\title{
The Reason for Miracles and the Miracles in Reason: Kant's Practical Conception of Miracles
}

\author{
Amit Kravitz \\ Ludwig-Maximilians-Universität, München, Germany \\ Email: Amit.Kravitz@campus.lmu.de
}

\begin{abstract}
The term 'miracle' generally refers to events that are not explicable by natural causes alone. Kant's notion of miracles is usually understood along these lines. However, Kant's occupation with miracles should be understood in a practical context. Belief in miracles plays a constitutive role in Kant's philosophy of religion concerning the need to strengthen the will both before and after departing from original evil. I demonstrate how my argument sheds new light on Kant's claim that theoretical reason precludes the possibility of material miracles.
\end{abstract}

Keywords: Kant; miracles; evil; religion of reason; positive religions

\section{Preliminary remarks}

Kant's ${ }^{1}$ Critical $^{2}$ conception of miracles has received little scholarly attention hitherto. ${ }^{3}$ Most studies of Kant's philosophy of religion address the issue marginally, if at all. ${ }^{4}$ Given that Kant developed an elaborate philosophy of religion which treats this issue at length, this (relative) lack of scholarly discussion seems peculiar; even denying the applicability of this concept - a position which, based on some of the formulations in $R G V$, might seem reasonable - would be a way of addressing this unavoidable issue.

My aim in this paper is to introduce a comprehensive practical rather than theoretical reading of Kant's treatment of miracles, and to show how the practical perspective might refine our understanding of the theoretical possibility of miracles according to Kant.

Systematic studies of Kant's conception of miracles thus far mainly focus on the theoretical perspective. An example of such theoretical treatment is one of Nuyen's claims according to which Kant's teleology 'dictates that reason must suppose the biggest miracle of all, the miracle of creation, or more specifically, the creation of a world suitable for human existence' (Nuyen 2002: 319). However, in RGV Kant explicitly holds that miracles are 'occurrences in the world' ( $R G V, 6: 86$ ); thus, as Kant says elsewhere, 'creation is no miracle' (V-Met/Mron, 29: 870). ${ }^{5}$ This direction will not occupy me here. 
Another example of a theoretical approach is Chignell's claim that 'the Causal Principles of the Analogies, as well as the dynamical-mechanical principles that result from their application to the concept of matter, are "universal and necessary" laws as far as the empirical world is concerned' (Chignell 2014a: 104), and thus cannot be broken and thereby exclude the possibility of miracles. (According to Chignell, 'Kant thinks we can prove this a priori'; ibid.). However, with respect to particular 'mechanical, dynamical, chemical, biological, and psychological principles ... Kant's picture does leave room for the occasional exception' (ibid.). Chignell draws on Kant's distinction in the Kiesewetter fragment between material and formal miracles (p. 111; see also Bonaccini 2015: 257ff.). Roughly: when an occasion is 'immediately affected' (KF, 18: 321) by divinity, it is considered a miracle of the material kind. In contrast, a formal miracle has a cause in nature, but the determination of this cause 'takes place outside the world' (Chignell 2014a: 111). Kant's example in KF, 18: 320-1, illuminates the meaning of this distinction, which is, as Chignell says, 'hardly transparent' (p. 110): if the splitting of the Red Sea in the Bible is an immediate effect of divinity, it counts as a material miracle; if it was caused by the wind, but the wind was sent by God, then it is a formal miracle. Chignell thereby claims that formal miracles can be considered possible according to Kant, for these cases are merely a divine 'complement' to natural laws. In contrast, material miracles are not possible, since they are 'opposed to the third law of mechanics, i.e., the application of the Third Analogy principle to our empirical concept of matter' (p. 111). Reichl agrees with Chignell concerning the inviolability of the law of effect and counter-effect; however, he adds that 'further conditions with respect to space in relation to the application of the third law pose a problem for the manner in which Chignell envisions ${ }^{6}$ such a [divine] complement' (Reichl 2019: 109). The question of the nature of spatiality (see also Peddicord 2001: 110ff.), then, plays a crucial role in any attempt to conceptualize, in Kantian terms, the intelligibility of a divine complement.

As mentioned above, in this article I address Kant's treatment of miracles from an entirely different perspective: the practical. Notably, in RGV Kant's whole discussion of miracles is subordinated ab ovo to this practical line of reasoning;; in Kant's words, 'we actually want to know what miracles are for us, i.e. what they are with regard to our practical use of reason' $(R G V, 6: 86)$. One of the implications of my argument is that the practical perspective might throw new light on the position that theoretical reason precludes the possibility of material miracles; for if it turns out that the practical realm necessitates a belief in such miracles, then this kind of miracle must be considered in some sense possible. An initial indication can be found in RGV, 6: 87, where Kant speaks of something which is represented (vorgestellt) as 'commanded by God in an immediate appearance (unmittelbare Erscheinung)', and adds that if this appearance opposes (widerstreitet) morality, then it cannot be held as a divine miracle. So from a practical point of view something which is held as an immediate divine appearance is not impossible as such, but only if it contradicts morality.

Since Kant addresses the issue of miracles mainly in the second general remark, let me say a preliminary word about the perplexing status (Michalson 1990: 90) of the four general remarks in $R G V$. Each remark is systematically related to the content of the respective chapter and tackles issues that on grounds of principle cannot be discussed elsewhere. ${ }^{8}$ Kant says that they serve as 'Parerga' (RGV, 6: 52), i.e. strictly speaking they do not belong to religion within the boundaries of bare reason alone, 
but they nevertheless 'border upon it' (ibid.). Reason 'cannot exclude the possibility or the actuality of the objects of this idea; it just cannot incorporate (aufnehmen) them into its maxims of thought and action' (ibid.).

This seems to contradict the sentence cited above: 'we actually want to know what miracles are for us, i.e. what they are with regard to our practical use of reason'. However, 'practical use of reason' is not identical to 'maxim of reason'. A moral agent cannot incorporate belief in miracles into the maxims of action, since it does not act morally because it awaits 'supernatural cooperation' ( $R G V, 6: 44)$. However, a 'nevertheless necessary supplement of the moral incapacity (Unvermögen)' (6: 52; my emphasis) is needed, for reasons I will clarify below. The fact that belief in miracles cannot serve as a maxim of action does not mean that it does not fulfil a necessary complementary function.

I will proceed as follows. Section 2 will present some background considerations. Section 3 will discuss the meaning of struggling with evil and the accompanying metaphysical constraints according to Kant. This section yields the first meaning of miracles in the practical realm: a necessary (in a sense which I explain in due course) supplement of the possibility of departing from original evil. In KF, 18: 320, Kant introduces a difference between 'inner' and 'external' miracles; adopting this terminology (without following Kant's precise intent in KF concerning this point), one can say that the first practical meaning of miracles I disclose is the inner one. Section 4 will discuss the second meaning of miracles in the practical realm: belief in miracles within positive religions (say, walking on water or a burning bush which is not consumed); in light of the terminology above, the second meaning of miracles is the external one, by which an occurrence in the world of senses, i.e. 'miracles in nature (Naturwunder)' (RGV, 6: 88) and not just in consciousness, is considered to be a divine interference. This belief seems redundant from a purely moral point of view, since it belongs to the contingent realm of positive religions. As I will show, however, Kant's position is much more nuanced. Section 5 will contain a brief summary and a discussion concerning one implication of my argument in Section 4 with regard to the claim that Kant's philosophy excludes the possibility of material miracles.

\section{Background considerations}

Before delving into details, let me present three relevant background considerations: (i) Kant's claim concerning the alleged dispensability of belief in miracles from a purely practical perspective; (ii) Kant's definition of miracles and the distinction between theistic and demonic miracles; (iii) the need for a moral revolution as described by Kant in the first piece ${ }^{10}$ of $R G V$.

As for (i) the alleged dispensability of miracles: Kant argues that in a pure moral religion belief in miracles is 'dispensable (entbehrlich)'; only when one wants to 'introduce' pure moral reason in positive ${ }^{11}$ religion, might one 'embellish (ausschmücken)' it with stories which include miracles, for without this embellishment, pure moral religion would allegedly not gain any 'authority' ( $R G V, 6: 84)$. Therefore, the belief in miracles seems to reveal an interesting (anthropological, psychological, sociological) fact about 'the common way of thinking' ( $R G V, 6: 84)$, but strictly speaking it has nothing to do with pure theology, i.e. it seems not to be a philosophical issue per se. Kant's stance can be summarized accordingly: in Wittgenstein's spirit, belief 
in miracles is 'the ladder that can be kicked away' (Chignell 2011:126; see also Chignell 2014b: 107-10) when reaching the realm of moral religion.

As for (ii) the definition of miracles and the distinction between theistic and demonic miracles: in the second general remark Kant suggests a definition of miracles ('supernatural revelation'; RGV, 6: 85). Kant writes:

However, when one asks what is understood under the word miracle, it can be explained (since we actually want to know what miracles are for us, i.e. what they are with regard to our practical use of reason) that they are occurrences (Begebenheiten) in the world, of which the laws of effect [or operation; Wirkungsgesetze] of their causes (Ursache) are absolutely unknown to us, and must remain so. ( $R G V, 6: 86)$

In KF, 18: 321, the definition is similar: 'miracle is an occasion (Begebenheit) whose ground (Grund) is not to be found in nature'. So in the practical context we do not define miracles differently than in the theoretical realm; both cases involve an occasion which seems to us not to have its ground in nature. The practical is an additional perspective on the same occasion, as we shall see in detail.

In light of this Kant draws a distinction between theistic and demonic miracles. In the theistic case, we can only have a 'general moral' concept of the laws of operation of their cause (i.e. a concept of an omnipotent, moral God); however, from this we cannot infer the specific laws by which God might occasionally 'allow nature ... to deviate from its laws' ( $R G V, 6: 86$; my emphasis). For example: God as a moral being acts by definition for the sake of the good, both when deciding to interfere (to allow a deviation from natural law) and when not; we as finite beings cannot obtain knowledge of the law ${ }^{12}$ according to which God decides to interfere in one case (say, preventing the sacrifice of an innocent child) and not in a different case (say, not preventing the death of another innocent child).

The fact that a miracle is not an occasion which absolutely violates laws, but only an occasion which seems to us (finite beings) as 'paradoxical (widersinnisch)' and from the practical perspective ought to be in the service of the 'moral use of reason' ( $R G V, 6: 88)$ holds true for the theoretical realm as well. As Kant says, such an event ought to generate 'hope to discover new laws of nature' which were unknown 'thus far' (ibid.), and not despair and loss of confidence in laws of nature.

Contrary to theistic miracles, of which reason can make 'moral use' (this will be discussed at length in the following two sections), demonic miracles - Kant refers mainly to those miracles which are caused by evil (diabolic) demons, for as he himself observes, there is 'little or nothing to say about good angels (I do not know why) in this respect ${ }^{\prime 13}$ - are 'the most incompatible with the use of our reason' (RGV, 6: 87).

As for (iii) the need for moral revolution: in the first chapter of RGV Kant famously presents two different theses. First ( $R G V, 6: 19-25)$, Kant argues that with regard to its propensity, which constitutes its 'fundamental attitude' (Gesinnung) ${ }^{14}$ the human being 'in its species' (6: 20) is either good or evil (exclusive disjunction). Secondly, Kant proves ${ }^{15}$ that the human being as a species is evil. Call this the argument for the universality of evil, bearing in mind that what is at stake is the moral "character of the species' (6: 29; see also $6: 21,25,29,32,38)$, i.e. the 'fundamental attitude' which designates every individual without exception. This 'universality of evil' does not 
refer to the preconditions of a free act (termed the 'predisposition to the good' at 6: 26-8), which are universal per definition, for they are original, necessary and thus belong to the very 'possibility of such a [free] being' (6:28), but to a free determination of the will (termed 'propensity to evil' at 6: 28-32). Being a consequence of a free act (possible 'only as a determination of the free will (Willkür)' (6: 29), the propensity is - contrary to the predispositions - 'contingent (zufällig)' (6: 28), and precisely because it is acquired by means of a free act we feel 'guilt (Schuld) ${ }^{16}$ concerning it.

of interest here are two important implications of Kant's argument: the nature of the first real (rather than ideal) free decision an individual can take; and whether the individual can execute this first free decision alone.

The first implication: assuming that the universality of evil (its ascription to every subject without exception) is proven, then every human agent - 'even the best' ( $R G V$, 6:30) - begins its moral life not in an ideal middle between good and evil, but rather in a state in which evil has 'already taken its place' $(6: 57,61)$. If the real point of departure of moral life (after a primordial evil determination of the will has taken place) is being 'sunk in evil' (6: 94), the first good act one can do, according to Kant, is not simply to opt for the good, but rather to 'depart from evil (ausgehen)' (6: 57), i.e. to struggle against the evil that has already taken place (see also e.g. 6: 66: 'evil, from which we depart (ausgehen)' as well as 6: 72: the agent 'started from evil'). So the first free decision is formulated in terms of moral revolution (and not only a reform; 6 : 47-9), i.e. a 'change of heart (Herzensänderung, Änderung des Herzens)' (6: 47).

The second implication: given that our point of departure is an agent 'sunk in evil' and freely (autonomously) wishing to depart from it, we ask whether it can fully perform this mission alone. Notice Kant's unique terminology in $R G V$ in this regard: "whatever good the human being can do on its own (für sich selbst) according to laws of freedom ... can be called nature', whereas 'the ability (Vermögen) which is possible for the human being only through supernatural assistance (übernatürliche Beihilfe) ... is called grace' (RGV, 6: 191). This terminology might be perplexing, for a free action in this context is termed natural action. ${ }^{17}$ So the question is: can the required departure from original evil be achieved naturally (the agent acts freely 'on its own'), or is supernatural assistance required?

\section{Struggle with evil and the first ('inner') sense of 'miracle'}

Given the point of departure of original evil, I wish to call attention to three issues: (i) a relevant difference between $K p V$ and $R G V$; (ii) the fact that an additional component besides original evil - the appearance of moral duty in consciousness - is generally described by Kant as something for which we in principle cannot tell its origin (ground); (iii) that this additional component is described in RGV (but not in KpV) in terms of an 'archetype' (or 'ideal') which 'has already taken place'.

Concerning (i) a relevant difference between $\mathrm{KpV}$ and $R G V$ : in $\mathrm{KpV}$ Kant presents an ideal (or, as he sometimes terms it, essential) picture of human beings (for a typical illustration see $\mathrm{KpV}, 5: 72$ ), that is, the structure of a (finite) will before any determination of the will has occurred. Kant's terminology attests to it: on the one hand, the human agent is aware of the binding demand of the moral law, and ought to make respect for it the sufficient incentive of the will. On the other hand, the human will is already affected - but not wholly determined - by the senses (5: 23; see also 
GMS, 4: 387). So the description here entails no determination of the will so far. After describing this point of departure Kant can explain what a moral action should look like, which conditions it has to fulfil and so on; this description stays valid, as Kant explicitly remarks, even if not a single agent has ever yet acted in this way (see, for instance, GMS, 4: 408; TP, 8: 384-5). The agent is not being described here as 'sunk in evil'; evil may or may not take place, since no determination of free will (Willkür) has yet occurred.

The description of the human being in RGV, as we have seen, is different; there, a (first, evil) determination of the will which is ascribed to the entire species and which renders our 'fundamental attitude' evil (thus serving as a 'stain (Fleck) of our species'; $R G V, 6: 38$ ) is assumed to have already taken place; we ('even the best') are 'sunk in evil'. ${ }^{18}$ As we shall now see, the appearance of moral duty in our consciousness in this state of distress obtains a different meaning than in $\mathrm{KpV}$.

Concerning (ii) the additional component (besides original evil) which is generally described by Kant as something whose origin we cannot know: I am referring to Kant's thesis that the consciousness of the moral law is not merely a 'fact of reason', but an 'original fact of reason'19 (sometimes called the 'voice of reason'; KpV, 5: 35).

As Kant stresses repeatedly, we can never explain how consciousness of the moral law emerges (see e.g. KpV, 5: 46). In RGV he uses the term 'secret' (or 'mystery'; Geheimnis) to illuminate this point; consciousness of the moral law (which according to Kant's celebrated thesis precedes and enables freedom; see e.g. Kant's example in $K p V$, 5: 30 , and see also $R G V, 6: 49)$ cannot be a secret, for as a fact its cognition (Erkenntnis) can be communicated (mitgeteilt) to everyone' (6: 138). By contrast, 'its inscrutable ground (Grund) is a mystery'. Kant uses a similar description concerning original evil: the agent cannot tell the 'first ground' which led to the 'acceptance (Annehmung)' of the original (evil) maxim (6: 21); this remains, as Kant says, 'inscrutable (unerforschlich)' (6: 21, 43).

However, despite the identical terminology concerning two primordial components whose origin is inscrutable, they do not have the same status. The second (original evil) relates to a propensity, the first (voice of reason) to a predisposition. That is, in the second case the agent cannot know the first ground of a free (contingent) primordial action (which is thus an accountable determination of the will), an action which - because it is evil - generates a feeling of guilt. In the first case, the agent cannot know the ground for the receptivity of an original (necessary) predisposition (appearing in this state of affairs as ideal), which is not the outcome of a contingent free act but might be said to constitute its moral facility, and therefore arouses hope rather than guilt.

Concerning the fact that (iii) this additional component - the appearance of moral duty in consciousness - is described in RGV (but not in $\mathrm{KpV}$ ) in terms of an 'archetype' (or 'ideal'): recall that we have seen that in $R G V$ the agent finds itself in a state in which evil has 'already taken its place' $(6: 57,61)$. In addition, notice that even in this state the agent ought to, thus can (see e.g. 6: 45, 62), depart from evil (call this the agent's moral possibility). We now ask: in this state of distress, how does Kant describe the appearance of the agent's 'ought to' (its moral possibility) in consciousness? The answer is threefold: first, Kant uses literally the same terminology concerning original evil ('taken its place') with regard to the appearance of morality in this state of distress; secondly, this moral possibility is now described in terms of an 'ideal' and 
'archetype of fundamental attitude' (and not just in terms of a 'fact of reason'); thirdly, it now appears as something which is connected to a divine ground, i.e. as something external which might strengthen our will to do as we ought.

To demonstrate: according to Kant, the human agent, being 'sunk in evil', should 'elevate' itself to what he terms in this context the 'archetype ${ }^{20}$ (Urbild) of the moral fundamental attitude (Gesinnung)' or 'ideal (Ideal) of moral perfection' (RGV, 6: 61). Kant notices: we are 'not the creator (Urheber) ... [of this archetype], but rather it has taken its place (Platz genommen) in the human being, without its being able to grasp (begreifen) how human nature can be receptive (empfänglich) to it'; this is why this 'archetype of moral fundamental attitude' is described by Kant as something external which has 'fallen from the sky upon us' (referring to John 6:38) ${ }^{21}$ or as 'lowering itself' ( $R G V, 6: 61)$. Kant adds: in this manner the archetype 'can give [us] strength (Kraft)' (RGV, 6: 61).

How are we to explain the fact that in the current state of distress moral possibility (i) appears as an 'ideal' or 'archetype of moral fundamental attitude' (and not just as formal consciousness of duty), and that (ii) it is represented as something which has 'taken its place' by 'falling from the sky upon us', and that (iii) this might 'strengthen' us? The first question concerns the content of moral possibility (appearing now in terms of 'fundamental attitude'); the second concerns its alleged origin, and the third the effectiveness of such an appearance.

To grasp this, recall that the loaded point of departure of RGV (being 'sunk in evil') regards precisely the 'fundamental attitude', which was proven in the first piece by Kant to be evil and not good. Thus, no wonder that the 'ought to' appears in RGV in specific relation to the ('stained') state of the fundamental attitude, i.e. in terms of the opposite (morally required) archetype of fundamental attitude. Now 'archetype' has two aspects: first, it concerns 'the moral fundamental attitude in its entire perfection, as an ideal of holiness which no created agent can achieve' (KpV, 5: 83); secondly and despite this metaphysical difference, it is an 'archetype (Urbild) to which we ought to approach (näheren) in a sustained, endless progression' (KpV, 5: 83). In the loaded state described in $R G V$, this archetype must appear as possible for us (i.e. the second aspect above should be emphasized), or else it would be devoid of practical use. So the content of this archetype must be presented as attainable and reachable, and this is why, when discussing the 'Objective Reality of this Idea' (RGV, 6: 62-7), the archetype is not described as something divine and unreachable. (For instance, Kant says that it should not be understood as too removed from the "natural human being (vom natürlichen Menschen)'; 6: 64.)

However, notice that even if the archetype's content ought not to be presented as unreachable for us (as divine), this does not mean that its origin cannot be divine. As Kant says, 'apart from its supernatural origin' (RGV, 6: 64; my emphasis) the content of the archetype ought not to be thought of as supernatural. The location of the appearance of the archetype is in reason ('the archetype ... is nowhere to be sought than in our reason', 6: 63, thus there is no need to assume that this archetype is 'hypostatized $^{22}$ in a particular human being'; 6: 64). In Kant's words, 'the archetype ... must always be sought in us (although we are natural human beings (obwohl natürlichen Menschen)' (6: 63); this contrast ('although we are natural human beings') tells the whole story: the 'existence (Dasein) of this archetype in the human soul is ... 
incomprehensible enough by itself (6: 64; my emphasis), ${ }^{23}$ thus at least might be linked to divinity.

Now what function does the possibility that the origin of the archetype is linked to divinity (i.e. not strictly natural) fulfil in this loaded state of affairs? The answer relates to the question of effectiveness mentioned above ('to give strength').

Kant writes: 'the incomprehensibility (Unbegreiflichkeit) of this predisposition to the good, [now] proclaiming (verkündigen) itself as having divine descent (Abkunft), must affect (wirken) the mind (Gemüt), strengthen (stärken) it . . . and generate enthusiasm (Begeisterung)' (RGV, 6: 49-50). The function of strengthening is thus central in the context of distress shared by the entire species; in this state of distress, the appearance of the predisposition (as having divine origin) serves 'as a means of awakening (Mittel der Erweckung)' (6: 50) for the agent.

This yields the first (inner) meaning of miracle in the practical realm (inner, for it does not concern an occasion in sensory nature which is held to have divine ground, but an occurrence in consciousness which is held to have divine ground): seeing the 'archetype of the moral fundamental attitude' as connected to divine interference ('fallen from the sky upon us') which 'lowers itself' in order to strengthen and awaken us to depart from original evil.

Before addressing four possible misconceptions in this regard, we first ask: given that according to Kant miracles are 'occurrences in the world', can the appearance of the archetype of fundamental moral attitude in consciousness be seen as an event in the world?

To understand how Kant generally approaches this issue, it is helpful to examine how he uses this expression ('in the world') in a different systematic context. In $\mathrm{KrV}$, A632/B660, Kant writes:

Natural theology infers the features (Eigenschaften) and the existence (Dasein) of an originator of the world (Welturheber) from the character (Beschaffenheit), order and unity which are encountered in this world, in which two kinds of causality and its rules are assumed, i.e. nature and freedom.

This indicates that Kant sees the issue of moral causality as an occurrence in this world (as something which might serve, just like physicotheology, as a point of departure for natural theology, which he terms ethicotheology; the fact that ethicotheology is for Kant a kind of natural theology speaks for itself). In the context of RGV this means that the archetype which is represented as 'fallen from the sky upon us' in order to 'strengthen' us counts as an occurrence in the world, for it assists the agent to freely decide to render itself an example of this ideal (that is, to freely begin, through this archetype, a chain of moral causation).

Now to turn to the four possible misconceptions, and then address a central debate in the literature on a related issue.

First, seeing the ideal to which we ought to elevate ourselves as linked to supernatural (divine) assistance (as 'fallen from the sky upon us') does not mean that our ability to actualize our moral capacity is dependent on divine action ('freedom itself ... entails nothing supernatural in its concept'; $R G V, 6: 191$ ). Linking the archetype to divine aid neither creates our ability to actualize our moral capacity nor determines our will, but merely draws our attention to the fact that even in this 
state of distress we obtain an original moral capacity to autonomously determine our will and depart from evil. In this primordial state of distress, 'the human being cannot reach to conviction (Überzeugung) [concerning the transformation to the good] in a natural way (natürlicherweise)' ( $R G V, 6: 51)$, i.e. on its own; ${ }^{24}$ given this apparent moral incapacity, a strengthening of the will in a non-natural way is (at least so far as one can tell) needed. (Recall that in this context 'whatever good the human being can do on its own ... can be called nature'; 6: 191).

Thus, first of all, what is at stake here is merely strengthening of the will by means of drawing attention to one's original power to set out on the departure from evil, and not the establishment of our moral power by divinity; to wit, it is not Kant's claim here that we cannot make moral judgements or recognize the moral law or its validity ${ }^{25}$ without assuming such a divine strengthening. Our moral facilities, as well as our ability to recognize and activate them, are utterly God-independent; however, in light of our primordial distress a need to further strengthening of the will, at least so far as we can see in that distress, arises.

Secondly, notice that the decision to depart from evil is not to be confused with regular moral decisions which require generalizations. Rather, it is a moral decision of a different (unique) kind: an unparalleled decision concerning the entire character (and not concerning this or that matter); to wit, it relates to a fundamental change of heart (the decision concerning the 'revolution in the fundamental attitude'; $R G V$, 6: 47), not to a decision on a specific occasion, such as whether to repay a loan. So it would be misleading to argue that every moral decision needs, at least so far as we can see, strengthening by means of divine assistance; this mechanism concerns solely the fundamental decision of departing from original evil.

Thirdly, notice that in light of the above we cannot argue that this need to strengthen the will (a divine 'drawing attention' to our original capacity in the primordial state of distress) is necessary in the sense that it can be demonstrated that all agents share it, as if the departure from evil is impossible without it. Quite the opposite: on the formal level, because the decision to depart from evil is rooted in freedom, it must be thought of as possible to carry out by the agent's own power; thus, the moral incapacity in question (being in the need of divine assistance to reach to conviction concerning the possibility of transformation to the good) is itself not objectively necessary. It seems that all that Kant can say is that there might be specific - weak - agents who, despite the fact that they can carry out the moral revolution on their own, nevertheless are in need of further strengthening.

However, some of Kant's formulations are in fact stronger; as we have seen, he maintains that 'the human being cannot reach to conviction [concerning the transformation to the good] in a natural way' ( $R G V, 6: 51$; my emphasis). Later Kant says that reason (i.e. freedom) is in need of a 'necessary ${ }^{26}$ supplement to its moral incapacity' (6: 52; my emphasis). How are we to account for these strong formulations given that, as I have said, it surely cannot be the case that it is impossible to carry out the moral revolution without this divine strengthening of the will?

To grasp this, recall that we are currently in a primordial state of affairs (before the awaited decision concerning moral revolution has taken place). In this context we simply have no reason yet to assume differences between agents, despite the fact that such a difference is surely possible. To understand Kant's unique line of reasoning in this regard, recall that Kant argues in a similar manner concerning the primordial 
context of the (free) act of falling into evil. According to him, 'the grounds that justify ascribing it [freely acquiring an evil rather than good "fundamental attitude"] to one person are constituted in a way that there is no reason to exclude any other human being from it' ( $R G V, 6: 25$; my emphasis). So despite its being rooted in a free (contingent) use of freedom, where one expects to find differences between agents, the primordial context gives us no attainable reason to assume such (definitely possible) differences. This holds true for the present context as well. Just like the state before falling into evil, the state before declaring departure from evil is still a primordial one which concerns the entire species; thus, if it is reasonable to ascribe a consciousness of moral incapacity (of the contingent need, at least so far as one can tell, of a strengthening of the will) to one person, we have no reason to exclude other agents from this account, even if it is not the case that anyone is objectively in need of such a strengthening.

Thus, Kant's strong formulations cited above are not accidental. Here I disagree with Pasternack when he limits the point to the following: 'it remains unknown to us whether our power, although necessary, may nonetheless not be sufficient for the Change of Heart ... we are ... unable to determine whether or not we can, unaided, come to make this decision [to depart from evil]' (Pasternack 2020: 116-17). It is true that Kant cannot deliver a demonstration which would show that every agent without exception must be aided; however, I have tried to show how Kant demarcates a territory between absolute necessity and utter contingency: The fact that the need of will-strengthening cannot concern absolute necessity (this would contradict freedom) does not necessarily mean that it is simply a matter of recognizing a contingency; given the primordial context, what is in question is a primordial consciousness - whether objectively valid or not - of a need for moral strengthening. Thus in this sense, just as with Kant's assertion of the 'universality of evil', which belongs to the realm of freedom (contingency) and nevertheless can be claimed to relate to the entire species, one can speak here of the 'universality of the need of divine strengthening'.

Fourthly, notice that in the current state of affairs divine assistance must be thought of as unmerited.$^{27}$ This is because divine strengthening precedes the awaited decision of moral revolution, thus cannot be explained as a remuneration given to specific agents due to their deeds. Only after unmerited divine strengthening is given to the entire species (to every agent without exception) might possible differences between individuals come into play (every specific agent might respond differently to divine strengthening which was given to all agents; one agent will comply with it, a second agent will reject moral revolution despite divine assistance and so on). ${ }^{28}$

As far as I know, eliciting in this manner this primordial (inner) sense of miracles cannot be found in the literature. Here are some representative examples. Michalson notices that "after all, if God "sees" the moral change in a way that supposedly works in our favour, the all-important change itself [moral revolution] must already have occurred. The element of grace here is thus not only besides the point - it is, as it were, after the fact' (Michalson 1989: 269); however, divine strengthening of the will occurs before moral revolution has taken place. Elsewhere Michalson argues that 'Kant's conception of grace and divine aid reintroduces an obviously Pelagian element based on human effort and merit' (Michalson 1990: 97); but again, divine interference at this stage must be thought of as unmerited, for it precedes the agent's decision to depart from evil. (Wolterstorff remarks in a similar misleading spirit that 'God must 
be understood in the Kantian scheme as required to forgive'; Wolterstorff 1991: 45.) Quinn ascribes to Kant the position that 'we can become morally better persons only if we receive divine assistance, and we will receive divine assistance only if we make ourselves worthy of it' (Quinn 1990: 421); however, there is no circularity at this primordial level, for here divine assistance is given before freely deciding to carry out moral revolution. Hare notes that 'Kant thinks that there must be an initial effort by a person, in order to merit this assistance' (Hare 1996: 61); however, in this state and as concerning not choice or effort, but the entire species, divine aid is unmerited. Mariña seems to present too strong a thesis: 'An explanation of the very change in the fundamental disposition itself in terms of divine activity ... means nothing less than God changing the whole character of the person. Kant does not deny that God may have such an effect on persons' (Mariña 1997: 386); however, and despite the fact that Mariña stresses the need to assure possible coexistence of such determination with human freedom, Kant's position does not go that far: moral revolution must be carried out by the agent applying its own power, and divine aid merely draws attention to the fact that the agent can make this decision on its own. ${ }^{29}$

\section{Positive religions and the second ('external') meaning of 'miracle'}

Thus far we have seen the first (inner) meaning of belief in miracles: belief in strengthening the will by means of divine assistance which precedes the departure from evil. As we shall now see, the second (external) meaning of miracles is put forward after the moral revolution was initiated, and concerns belief in specific miracles which can be found in every positive religion (or at least, in those in which Kant had a systematic interest).

To grasp the next step, one needs to examine how Kant understands the transition from chapter 2 to chapter 3 of RGV. Kant named the second chapter 'On the Struggle', and the third 'Triumph over the Evil Principle'. Why?

According to Kant, the second chapter merely concerns the launching of the struggle, the initial act of 'breaking' ( $R G V, 6: 83)$ with the power of evil. It does not concern the triumph itself, the awaited 'defeat of the evil principle, for its kingdom (Reich) still endures' (6: 82). Launching the struggle - an inner manoeuvre in which belief in divine interference plays a role - is thus merely the beginning of a process which eventually should lead to the rising of 'a new era, in which [evil] should be destroyed' (6: 82.).

Further considerations lead Kant to conclude that this last expected era cannot be achieved immediately, i.e. that the duration of the struggle over time is metaphysically necessary. ${ }^{30}$ The best way to grasp this point is to note that Kant now adds a third component which is also described - just like the archetype of fundamental moral attitude and original evil - as something which 'has already taken place'.

Assuming that the departure from original evil was announced and that the process of moral revolution has begun: can the agent triumph over evil on its own from now on? Kant's description of the current state of the agent entails two relevant aspects, both of which are related to the fact (which is not precisely an empirical fact, as I will explain) that the individual finds itself 'among people' (RGV, 6: 94). The first aspect concerns one major consequence of this being-among-people: 'It is not even necessary to assume', as Kant says, 
that they [other agents] are already sunk in evil, functioning thus as seductive examples; it is enough that they are there, that they surround the individual, and that they are human beings, in order for them to mutually corrupt their moral predisposition and render one another evil. (6: 94)

So even if the individual freely decides to break with the original evil, it is insufficient. The agent will repeatedly be 'under the danger of falling back into evil' due to the factuality of being-among-people, unless some 'means' are found to prevent it ( $R G V, 6: 94)$. (Call this again the need to strengthen the will, this time not before but after the moral revolution has been launched.) Given that the threat is defined in terms of the existence of other people, the required means to remove it must be thought of in terms of a 'society' whose aim is to 'preserve morality' (RGV, 6: 94).

The second aspect concerns the precise definition of the threat, i.e. the meaning of being-among-people. Significantly, Kant does not refer to an abstract beingamong-people, but to finding oneself 'in an already established political entity' ( $R G V$, 6: 95; my emphasis). Thus, the genuine meaning of establishing a moral society - also termed 'republic of moral laws' (6: 98) or 'empire of virtue' (6: 95) is to start an (endless) process of transformation of the political realm to the ethical. In Kant's terminology, being-among-people, i.e. being in the political state of affairs, means being 'in an ethical state of nature' (ibid.). It is not a state of nature per se in the sense of a war of everyone against everyone (à la Hobbes), for the community (the political order) already exists, but it is still not the universal ethical society which we freely should establish to be in a position to fully triumph over evil. So the agent not only has to break with original evil which has already taken its place (launching moral revolution), but it also has to then break with the tendency to depend on the political order which also has already taken its place and which tempts it to fall back into evil.

Kant sees this unique duty to establish a universal moral republic as the duty of humankind towards itself as a species $(R G V, 6: 97),{ }^{31}$ beyond political differences. This special duty requires the idea of a higher moral being as its originator, for the powers of finite beings alone cannot yield the anticipated effect $(6: 98,152)$. This is precisely what Kant refers to as a 'religion of reason'. So the difference between the political state and the anticipated universal moral state (perceived of as a 'religion of reason' because it involves the idea of God as its originator) does not pertain merely to the fact that the first addresses a particular, political community, whereas the second should apply to humanity as a whole. Rather, it is a categorial difference: the political order, contrary to the order of the ethical state, can be established and maintained without the idea of a divine moral creator at its base.

Now notice that the state of affairs of being-among-people, which leads to the need to establish a religion of reason ('republic of moral laws'), is still not in the realm of positive religions (or 'historical faiths', as Kant occasionally terms it; RGV, 6: 103). In the religion of reason we think of God as the originator of this pure moral republic and obtain 'cognition of our duties as divine commands' (KpV, 5: 129; KU, 5: 481). In contrast, in the realm of positive religions - in which the belief in concrete miracles arises according to Kant - we further assume that divinity revealed itself in the world of the senses in a specific time and place and that divinity is in need of an additional service besides morality. After accounting for the transition from morality to religion 
of reason, how is the additional transition from religion of reason to the realm of positive religions (revelations) explained? Kant writes:

However, a particular weakness of human nature is guilt over the fact that this pure fact can never be counted on as much as it presumably deserves, i.e. to establish a church on it alone ... it is not easy to convince human beings that the only thing God requires from them is the firm eagerness (Beflissenheit) towards a moral transition of their lives ... they cannot think of their duty except as a service they have to give God .... and in that manner emerges the concept of service to God instead of the concept of a pure moral religion. (RGV, 6: 103)

What Kant points to should not be understood simply as a sociological, anthropological or psychological claim, as if one day people would not link their idea of duty with the idea of service (e.g. if they had read Marx and understood that this state of affairs is nothing but the consequence of contingent social Produktionsverhältnisse); rather, it is something rooted in finitude itself, a component which cannot be fully overcome. One clear indication of this is Kant's terminology; when referring to this unavoidable tendency to understand pure duty in terms of service, Kant uses the same concept he employed concerning original evil: the 'propensity' (Hang; that is, something which pertains to the entire species, above and beyond all sociological, psychological or anthropological differences) to shift from 'pure moral religion' to a 'service-to-God religion' ( $R G V, 6: 106)$. Here, also, the necessity of this shift does not imply a formal contradiction - the concept of a pure moral religion which does not entail the transition to positive religions is perfectly intelligible; rather, it is a real necessity, arising from the real point of departure of human agents which entails at least a sense of inherent weakness which Kant ascribes to their 'nature'. In light of this, it is impossible to absolutely overcome this state of being in need of some positive, particular faith (an absolute overcoming is an ideal, possible only formally in the sense of not entailing formal contradiction, but actually it is the object of endless convergence) ${ }^{32}$ Similarly, Kant mentions the "natural need (Bedürfnis) of all human beings to demand something sensibly sustainable (etwas Sinnlichhaltbares) for the highest concepts of reason ..., some historical church faith (Kirchenglaube)' (6: 109).

Thus, we see that Kant's celebrated determination that 'morality leads inescapably (umumgänglich) to religion' ( $R G V, 6: 6$; see also KpV, 5: 129) should be understood as entailing two transitions. The first concerns morality leading inescapably to pure moral religion, i.e. to the above mentioned 'republic of moral laws' in which God is thought of as its originator and in which God is in no need of any particular service besides morality. However, due to the inherent weakness of human nature described above, pure moral religion, which as an ideal can never be an 'object of possible experience' (6:101), leads inescapably (this is the second transition) to the realm of positive religions, i.e. to a realm in which the question of how God is to be worshipped 'cannot be answered through mere reason (bloße Vernunft)' (6: 105). Thus, the shift to the realm of positive religions is not something external to pure moral religion, just as pure moral religion itself is not external to pure reason (morality). Such a description is too formal, and ignores the rich - real - background which constitutes Kant's position. 
We can now better grasp Kant's discussion of belief in particular miracles (say, walking on water, or an unconsumed burning bush); this belief is a constituent component of positive religions, to which reason 'inescapably' leads.

One possible reservation might be: why is belief in specific miracles a constitutive component of positive religions at all? Granted that we are indeed inescapably led to the realm of revelations; still, cannot one be a member of such a community of historical faith without subscribing to its accounts of miracles? The rejoinder here is two-fold.

The first answer is technical: 'revelation' is a specific divine appearance in the world of senses (e.g. Mount Sinai), i.e. it is based on at least one miracle by definition. One can reject some, or most accounts of miracles but not all of them if one is committed to a specific historical faith, for a concrete faith entails by definition more than merely seeing moral duties 'as divine commands'.

The second more critical answer can best be elicited, I think, from a letter which Kant sent to Fichte ${ }^{33}$ on 2 February 1792, discussing the need to strengthen the will in the practical context. More specifically, it concerns Kant's response to Fichte's determination that 'the belief in a given revelation cannot be rationally (vernünftmäßig) grounded on the belief in miracle'. In essence, Kant agrees with Fichte about the 'subjective necessity (subjective Nothwendigkeit) of revelation' - what I termed the second transition (from religion of reason to revelation), ${ }^{34}$ and the question at stake regards only the relation to belief in miracles within this realm. Kant's reply to Fichte is two-fold.

First, Kant advises Fichte not to articulate his position in such a manner; however, his ground is not philosophical. According to Kant, Fichte's claim that belief in a given revelation cannot entail in principle other 'articles of faith (Glaubenartikel)' besides 'bare pure reason (bloße reine Vernunft)' will most likely be rejected by the censorship, which tends to understand the holy scripture 'literally (nach dem Buchstaben)'.

Secondly, however, Kant adds a piece of practical advice concerning an alternative formulation that the censorship might allow, but that also captures Kant's genuine position on this issue. Kant advises Fichte to establish the difference between a dogmatic belief in miracles, which stands beyond any doubt, and a mere (blos) moral belief in miracles, which can be given moral grounds: 'The insufficiency (Unzulänglichkeit) ${ }^{35}$ of reason'. In this case, belief in miracles within 'religious faith (Religionsglaube)' is justified if it encourages pure moral belief by giving it 'support (Unterstzützung) through miracles'. Regardless of whether such reasoning is useful against the censorship, ${ }^{36}$ the point is that it obtains a genuine moral justification. Due to the inherent weaknesses of human nature depicted above, the need to further strengthen the will through complementary belief in miracles is rendered reasonable. Significantly, what is at stake here is merely a strengthening of the will, not belief in miracles as incentive of the will (this amounts to heteronomy); the initial determination of the will precedes this belief, as it precedes the need to establish a 'republic of moral laws' or the need to further move to the realm of 'revelation'. Thus, even if Kant grants that 'revelation' can indeed be thought of ideally - from its concept - without the additional need to strengthen the will by believing in miracles, from a real perspective (which determines Kant's entire religious project) this is not the case. ${ }^{37}$

Another indication of Kant's intent is the grammar. In RGV, 6: 84, Kant does not say that in pure moral religion belief in miracles is redundant (this is certainly true); 
rather, he uses a conditional: if pure religion is established, then within it belief in miracles is rendered redundant. ${ }^{38}$ However, as previously seen, a pure moral religion can never be an object of possible experience. Rather, it is an idea, a horizon towards which one should continually and endlessly strive. ${ }^{39}$ Wittgenstein's ladder mentioned above does not capture Kant's intent here, for we would never be in a position to kick away the vehicle of positive religion and the belief in miracles within it.

In light of this morally justified need for belief in miracles, all that remains, as Kant writes in this letter, is to suggest a criterion of judgement of miracles, which must of course be rooted in morality (reason): a miracle must contribute to what Kant refers to in this letter as the 'inner improvement (innere Besserung)' of the agent. Thus, from the practical perspective reason cannot render belief in miracles redundant; given that we are led to this realm 'inescapably', reason only provides the criterion - since, from a theoretical perspective, 'we cannot exclude the possibility or the actuality of the objects of this idea' $(R G V, 6: 52)$ - to distinguish between what can be considered a miracle 'with regard to our practical use of reason' (6: 86) and thus can strengthen our will ('theistic miracles') and what not ('demonic miracles').

\section{Summary and remark on the practical possibility of material miracles}

Kant's practical treatment of miracles reaffirms the relatively recent (in my view justified) trend in Kant scholarship which maintains that the intricate relation between morality and religion in his philosophy cannot be described simply in terms of an (exhaustive) reduction of religion to morality.

As demonstrated, in Kant's philosophy of religion the belief in supernatural (divine) interference plays an indispensable role with regard to two important contexts. First, it serves as an indispensable moment of strengthening of the will before the primordial decision for moral revolution takes place (in relation to the need to launch the struggle against evil). Secondly, it serves as an inescapable moment of strengthening of the will after the primordial decision for moral revolution has taken place (in relation to the need to fully triumph over evil). In both cases belief in miracles is not necessary on the pure formal level; however, it is inescapable given the real (not the ideal) background in which the finite agent acts.

The second meaning of belief in miracles - the belief in specific miracles within positive religions - demonstrates how the practical point of view might not always fully comply with our theoretical understanding of miracles. Recall that according to some positions in the literature, Kant can exclude the possibility of material miracles (an immediate effect of divinity in nature, contrary to formal miracles, occasions which have their cause in nature, but the determination of this cause takes place outside the world). However, the practical point of view sheds new light on this exclusion; the unavoidable need for believing in miracles (e.g. in the splitting of the Red Sea for the 'passage of the children of Israel'; KF, 18: 321) simply means believing that God is the immediate ground of this occasion. For in the realm of positive religions, divine interference in nature is represented as an occurrence 'commanded by God in an immediate appearance (unmittelbare Erscheinung)' (RGV, 6: 87). (This corresponds with the point of view of the common believer: it was God who split the sea.) And according to Kant's practical line of reasoning, finite beings who are subordinated to an endless process of moral implementation can never find themselves in a context 
in which belief in immediate divine influence is rendered fully redundant. Confronting 'semblances (Anschein)'; RGV, 6: 87) of events that seem to be an expression of divine interference ought to encourage agents from the theoretical perspective, as Kant says, to find new laws; for it is always possible that a certain event which is perceived as a miracle will be given a scientific explanation. From a practical perspective, however, given that we find ourselves by definition in a context which requires such a belief in order to fortify our will, it is not possible that all miracles will be explained scientifically.

The tension between Kant's theoretical position as rightly described by Chignell, whereby it can be demonstrated a priori that 'material miracles' are not possible ${ }^{40}$ and Kant's practical approach which leads inescapably to belief in such occurrences, cannot simply be solved by Kant's celebrated stance that reason and faith ought not to clash, for the context of material miracles raises unique difficulties. To grasp this, compare it to Kant's claim that we cannot theoretically demonstrate God's existence. This determination expresses an a priori limitation of our knowledge, but it is neutral concerning the issue at stake; this is precisely why postulating God's existence on practical grounds does not clash with it. In contrast, the claim that it can be demonstrated a priori that material miracles are not possible entails a positive exclusion of their possibility, an exclusion which seems incompatible with the inevitable practical need to assume them. This tension cannot be solved simply by claiming that what seems from the believer's perspective to be divine immediate affections 'ex nihilo' (Chignell 2014a: 111) in nature is actually subordinated to an ultimate law which we simply cannot cognize (see the discussion in section 2); for precisely this view annuls the content of the practical belief. Fully accounting for this tension deserves a separate discussion; however, it is important to notice that this tension is unique and cannot be conflated with, for example, the case of God's existence, where it can easily be shown that faith and reason do not necessarily clash.

Regardless of this specific challenge, Kant's rich discussion on miracles reveals that Kant did not just look for a solution to a classic question in the philosophy of religion, but rather presented an encompassing philosophical theology, in which belief in miracles plays an 'inescapable' role. ${ }^{41}$

\section{Notes}

1 I will use the following abbreviations: GMS = Grundlegung der Metaphysik der Sitten; KF = Kiesewetter fragment (Über Wunder); KpV = Kritik der praktischen Vernunft; $K U=$ Kritik der Urteilskraft; $\mathrm{KrV}=$ Kritik der reinen Vernunft; $\mathrm{MpVT}=$ Über das Mißlingen aller philosophischen Versuche in der Theodicee; $R G V=$ Die Religion innerhalb der Grenzen der bloßen Vernunft; TP = Über den Gemeinspruch: Das mag in der Theorie richtig sein, taugt aber nicht für die Praxis; V-Met/Mron = Metapysik Mrongovius. All translations in this article are mine.

2 For Kant's pre-Critical conception of miracles see e.g. Peddicord 2001: 73-100; for a general approach to Kant's philosophy of religion through an examination of his pre-Critical work see Huxford 2018.

3 For a similar evaluation see Reichl 2019: 105.

4 To give several representative examples. This issue is not addressed in Wood 1970, 1978 or 1992. In Wimmer 1990 Kant's conception of miracles is not discussed as a separate issue, nor in sections dedicated to reason and revelation (pp. 168-86); this also holds true for Winter 2000, as well as Dierksmeier 1998. In selections of papers dedicated exclusively to Kant's philosophy of religion this issue is seldom addressed; for example: Fischer 2004, Essen and Streit 2005.

5 For a detailed critique of Nuyen's position see Reichl 2019: 106-7. 
6 Chignell 2014a: 113ff.

7 As we shall see, understanding Kant's order of discussion is essential to following his line of reasoning in the context of philosophy of religion.

8 For an enlightening discussion see Palmquist 2009: pp. xliii-xlv. See also Palmquist 2016.

9 There is a sense of 'for us' that can be attached to empirical appearances as opposed to things in themselves; however, this ought not be conflated with Kant's intent in the practical realm. The practical is defined in terms of a mission (Sollen is a task by definition; only a divine will is determined 'of itself ... only by the representation of the good'; GMS, 4: 414, my emphasis), carried out by means of free (contingent) decisions. For the sake of the possibility of fully accomplishing this mission (i.e. for the sake of the implementation of morality), we postulate ('for the practical use of our reason'; KU, 5: 456) diverse components - e.g. the existence of a divine being.

10 As Stephen R. Palmquist notes, the word Stück appears to remind readers that RGV consists of four essays originally written as a series of journal articles; see Palmquist 2009: p. xviii.

11 Kant uses the term 'positive' in this context (e.g. in RGV, 6: 157).

12 Since Kant defines divine will as obtaining a necessary reference to a law (divine will is determined per definitionem by the 'representation of the good'; see my note 9), it is clear that this will cannot be arbitrary. This has interesting consequences. For example, according to Kant, God's goodness is subordinated to God's holiness (MpVT, 8: 257); this is so, because if God activated goodness (prevented pain in rational beings) arbitrarily (i.e. not as remuneration for those who first made themselves worthy of it), it would destroy the very concept of God as a moral being. In cases such as the biblical Job (MpVT, 8: 265ff.), an agent is worthy of God's goodness, but does not receive it. But from this we ought not to infer that God's action is arbitrary and lacks reference to a law, but only that we - finite agents - cannot understand the specific law of divine intervention (or lack thereof).

$13 R G V, 6: 86$. Kant does not explain his determination here, but aside from the fact that he later says that the evil spirit sometimes 'disguises itself as an angel of light' (6: 87), he might also be suggesting that it is difficult to distinguish between theistic and (good) angelic miracles, for in both cases - contrary to diabolical miracles - the miracle corresponds with morality, and can be ascribed either to God or to a good angel.

14 I follow Palmquist 2009: p. xxviii in translating Gesinnung as 'fundamental attitude'.

15 Kant explicitly uses the term 'proof' in this context; see RGV, 6: 25, 30, 39. There is a debate among scholars about whether Kant actually delivers such a proof, or just gives empirical examples instead of a proof (reading 6: 32-3 one might conclude that Kant holds that the empirical examples replace the promised proof). I cannot develop this issue here; for one lucid account see Buchheim 2001.

16 See explicitly in RGV, 6: 38, where Kant speaks of 'inborn guilt'; Kant stresses that being 'inborn' does not contradict 'freedom' (if it were something purely natural and not accountable, it would not generate guilt).

17 Since 'concerning this ability we can at least recognize the laws (virtue)'; RGV, 6: 190.

18 I am not getting into the question of whether Kant first thought of the issue of a supreme maxim in $\mathrm{KpV}$ or only afterwards; in $\mathrm{KpV}$, 5: 99-100, for example, one might elicit such a line of thought.

19 See e.g. Wolff 2009; Ware 2014.

20 See Firestone and Jacobs 2008: 155-69.

21 Kant uses Christian motifs here, but he does not describe Christianity yet, for the issue of the systematic transition to the realm of positive religions as such is not yet raised (see my detailed discussion in section 4). Christian motifs are merely used to illustrate an independent essential component. 22 Due to its alleged divine origin this archetype is also called 'God's son'. For a claim that Kant's discussion is not in line with major Christian components (e.g. with resurrection or with Trinity) see Yandell 2007; for a different position see e.g. Firestone 2009: 139-63.

23 Incidentally, precisely this distinction bothered Fichte in his Versuch einer Kritik aller Offenbarung (1792) - i.e. the distinction between the assumption that the content of the moral law is identical for us and for God, and the additional claim that God is also the 'cause of the existence of the moral law in us' (Fichte 1971: 57; my emphasis). Fichte clearly draws on a subtle Kantian problematic here.

24 In Fichte's Sittenlehre (1798) there appears a somewhat similar structure. Fichte asks: 'what does the agent lack [in order to get out of original evil]? Not power ( $\mathrm{Kraft}$ ), which it already obtains, but consciousness of it and the incentive (Antrieb) to use it. This cannot come from within (von innen)' (Fichte 1995: 201-2). The agent must find other agents to serve as a model (Muster) to which it can elevate 
itself. But how did these 'model agents' elevate themselves to morality in the first place? Here Fichte speaks of a 'real miracle (wahres Wunder)', which was 'effected (bewirkt) by a spiritual, intelligible being outside of themselves (außer ihnen)'.

25 See e.g. Kant's clear words on the moral demonstration of the existence of God in KU, 5: 450-1: 'This proof ... does not mean that it is just as necessary to assume (annehmen) the existence of God as it is to acknowledge (anerkennen) the validity of the moral law, hence that whoever cannot convince himself of the former can judge himself to be free from the obligations of the later. No!'

26 In German: 'was aber doch zu Ergänzung des moralischen Unvermögens nothwendig wäre'; this 'wäre' is not to be translated as 'may however be necessary', but as 'is necessary'. That is, given our moral incapacity (the need to strengthen the will, which is in itself not necessary), this supplement is necessary. 27 Without getting into Kant's specific reasoning in each step, his argument can be presented schematically as follows: (1) given original evil, a change of heart ought to be realized; (2) departing from original evil means to render oneself an example of the archetype; (3) this archetype appears, indeed, in reason, but its origin remains essentially incomprehensible, thus it is seen in the context of distress as related to divine assistance (strengthening the will, i.e. drawing attention to our original capacities before departing from evil); (4) given that the question of such divine assistance precedes moral revolution, it cannot be seen yet as a matter of reward for our concrete deeds - it is seen as a matter of unmerited grace; (5) it has been argued above that the need for this grace is, in the subjective sense there explained, 'universal' (concerns every agent).

28 In Kant's first general remark one can find evidence for two distinct approaches. On the one hand, there are formulations implying that divine aid is merited; see e.g. RGV, 6: 44, where Kant says that supposing that divine cooperation is necessary, it only consists of 'diminution (Verminderung) of obstacles, or also of positive assistance; the human being must make itself worthy to receive this divine cooperation beforehand'. On the other hand, there are formulations in which divine aid 'serves as a means of awakening the moral divine fundamental attitude' (6: 50), i.e. formulations implying that the function of divine assistance precedes the free determination of the will. Taking Kant's order of discussion in $R G V$ into account we see that the unmerited divine assistance comes first, for it concerns the primordial state of affairs.

29 I share Pasternack's position: 'divine aid ... instead of doing the moral work for us, rather supports the use of our own powers' (Pasternack 2020: 115; my emphasis).

30 The temporal character of the struggle which I unfold next comports with Kant's transcendental idealism. In the realm of morality, only the validity of the imperative is not time dependent; its full implementation (Verwirklichung) is a different issue, which necessitates launching a process (such as the establishment of a community, as we shall see). See Stern 1986.

31 See e.g. Städler 2013.

32 In one revealing formulation Kant speaks of humans as 'beings-in-the-world (Weltwesen)', subordinated to 'continually becoming (kontinuierliches Werden)'; RGV, 6: 74-5.

33 The citations from this letter are from Kant's Briefwechsel, 11: 321-2.

34 This was, in fact, the theme of Fichte's 1792 Versuch einer Kritik aller Offenbarung - which is central to the correspondence between Kant and Fichte cited here: 'Since the appearance of the Critique it has often been asked: How is revealed religion possible?'; Fichte 1971: 63.

35 This line in Kant's letter is almost identical to RGV, 6: 52, where Kant speaks of reason which is 'conscious of its incapacity (Unvermögen) to deal adequately (Genüge zu tun) with its moral need (Bedürfniß)'; in the letter Kant mentions the 'insufficiency (Unzulänglichkeit) of reason to fulfil itself (selbst Genüge zu leisten) in view of its need (Bedürfnis)'.

36 Kant says that this reasoning amounts to saying that 'my non-deliberate not-believing (unvortsätzlicher Nichtglaube) is not a deliberate non-believing (vorsätzlicher Unglaube)', thus (maybe) it leaves enough room for the censor to approve it nevertheless, for it does not amount to a positive rejection of miracle accounts in the holy scripture.

37 Thus, Kant's description according to which 'wise governments' (RGV, 6: 85) or a hypothetical authority of a certain positive religion occasionally makes use of the belief in miracles should be understood as follows: such governments make (often amiss) use of something which is originally rooted in an authentic justified need of reason - its in-principal insufficiency described above. 
38 The 'if' (Wenn) can be translated as 'when'. This, however, does not change the meaning of what I am claiming, because this 'when' does not designate a specific possible time: it is an ideal that can never come fully into being. For a discussion in the same spirit see Palmquist 2015.

39 There are roughly two approaches to comprehending the relation between morality and religion in Kant's philosophy: a reductionist view and a position according to which religion obtains an irreducible status in Kant's moral theory. Three examples of comprehensive studies which represent the second approach, with which my argument in this paper corresponds, are: Hare 1996; Byrne 2007; Palmquist 2000.

40 I refer here only to Kant's position, which is based on a Newtonian picture of nature, without claiming that there are no possible ways (which lie, as it were, beyond the horizon of Kant's thought) to reconcile this kind of miracle with causal lawfulness. However, this issue is beyond the scope of this paper.

41 I would like to thank Kantian Review's anonymous readers and Prof. Richard Aquila for their helpful comments.

\section{References}

Bonaccini, Juan B. (2015) 'Kant's Account of Miracles in his Lectures on Metaphysics'. In Bernd Dörflinger, Claudio La Rocca, Robert Louden and Ubirajara Rancan de Azevedo Marques (eds), Kant's Lectures/Kant's Vorlesungen (Berlin/Boston: de Gruyter), 247-60.

Buchheim, Thomas (2001) 'Die Universalität des Bösen nach Kants Religionsschrift'. In Gerhardt Volker, Rolf Horstmann and Ralph Schumacher (eds), Kant und die Berliner Aufklärung (Berlin/New York: de Gruyter), 652-61.

Byrne, Peter (2007) Kant on God. Aldershot: Ashgate.

Chignell, Andrew (2011) 'The Devil, the Virgin and the Envoy: Symbols of Moral Struggle in Religion, Part Two, Section Two'. In Otfried Höffe (ed.) Die Religion innerhalb der Grenzen der bloßen Vernunft (Berlin: Akademie Verlag), 111-30.

- (2014a) 'Can Kantian Laws be Broken?'. Res Philosophica, 91, 103-21.

_ (2014b) 'Rational Hope, Possibility and Divine Action'. In Gordon E. Michalson (ed.), Religion within the Bounds of Mere Reason: A Critical Guide (Cambridge: Cambridge University Press), 98-117.

Dierksmeier, Claus (1998) Das Noumenon Religion: Eine Untersuchung zur Stellung der Religion im System der praktischen Philosophie Kants. Berlin/New York: De Gruyter.

Essen, Georg and Magnus Streit (eds) (2005) Kant und die Theologie. Darmstadt: Wissenschaftliche Buchgeselschaft.

Fichte, Johann Gottlob (1971) Versuch einer Kritik aller Offenbarung. In Werke, vol. 5. Berlin: De Gruyter.

_ (1995) Das System der Sittenlehre nach den Prinzipien der Wissenschaftslehre (1798). Hamburg: Meiner.

Firestone, Chris L. (2009) Kant and Theology at the Boundaries of Reason. Burlington, VT: Ashgate.

Firestone, Chris L. and Nathan Jacobs (2008) In Defense of Kant's Religion. Bloomington, IN: Indiana University Press.

Fischer, Norbert (ed.) (2004) Kants Metaphysik und Religionsphilosophie. Hamburg: Meiner.

Hare, John E. (1996) The Moral Gap: Kantian Ethics, Human Limits, and God's Assistance. Oxford: Clarendon Press.

Huxford, George (2018) 'Evil, the Laws of Nature, and Miracles'. Kant Yearbook, 10, 43-62.

Mariña, Jacqueline (1997) 'Kant on Grace: A Reply to his Critics'. Religious Studies, 33, 379-400.

Michalson, Gordon E. (1989) 'Moral Regeneration and Divine Aid in Kant'. Religious Studies, 25, 259-70.

_ (1990) Fallen Freedom; Kant on Radical Evil and Moral Resignation. Cambridge: Cambridge University Press.

Nuyen, A. T. (2002) 'Kant on Miracles'. History of Philosophy Quarterly, 19, 309-23.

Palmquist, Stephen R. (2000) Kant's Critical Religion: Volume Two of Kant's System of Perspectives. Aldershot: Ashgate.

_ (2009) 'Introduction'. In Kant, Religion within the Bounds of Bare Reason, trans. Werner S. Pluhar (Indianapolis/Cambridge MA: Hackett Publishing Company, Inc.), pp. xx-xlix.

- (2015) 'Kant's Prudential Theory of Religion: The Necessity of Historical Faith for Moral Empowerment'. Con-Textos Kantianos. International Journal of Philosophy, 1, 57-76. 
- (2016) Comprehensive Commentary on Kant's Religion within the Bounds of Bare Reason. Chichester: Wiley Blackwell.

Pasternack, Lawrence (2020) 'On the Alleged Augustianism in Kant's Religion'. Kantian Review, 25, 103-24.

Peddicord, Clark (2001) Die Wunderkritik Immanuel Kants. Giessen: Geisteswissenschaften OnlinePublicationen.

Quinn, Philip (1990) 'Saving Faith from Kant's Remarkable Antinomy'. Faith and Philosophy, 7, 418-33.

Reichl, Pavel (2019) 'Leaving the Enchanted World Behind: Kant on the Order of Nature, Empirical Space and the Possibility of Miracles'. Kantian Review, 24, 103-25.

Städler, Michael (2013) 'Kants Religionsbegriff als kosmopolitisches Modell der Moral'. In Margit Ruffing, Claudio La Rocca, Alfredo Ferrarin and Stefano Bacin (eds), Kant Und Die Philosophie in Weltbürgerlicher Absicht: Akten des XI. Kant-Kongresses (Berlin: De Gruyter), 963-74.

Stern, Paul (1986) 'The Problem of History and Temporality in Kantian Ethics'. Review of Metaphysics, 39, 505-45.

Ware, Owen (2014) 'Rethinking Kant's Fact of Reason'. Philosopher's Imprint, 14, 1-20.

Wimmer, Reiner (1990) Kants kritische Religionsphilosophie. Berlin/New York: De Gruyter.

Winter, Aloysius (2000) Der Andere Kant. Zur philosophischen Theologie Immanuel Kants. Hildesheim: Olms. Wolff, Michael (2009) 'Warum ein Faktum der Vernunft ein Faktum ist: Auflösung einiger Verständnisschwierigkeiten in Kant's Grundlegung der Moral'. Deutsche Zeitschrift für Philosophie, 57, 511-49.

Wolterstorff, Nicholas (1991) 'Conundrums in Kant's Rational Religion'. In Philip J. Rossi and Michael Wreen (eds), Kant's Philosophy of Religion Reconsidered (Bloomington, IN: Indiana University Press), 40-53.

Wood, Allen W. (1970) Kant's Moral Religion. Ithaca, NY, and London: Cornell University Press.

- (1978) Kant's Rational Theology. Ithaca, NY, and London: Cornell University Press.

(1992) 'Rational Theology, Moral Faith, and Religion'. In Paul Guyer (ed.), The Cambridge Companion to Kant (Cambridge: Cambridge University Press), 394-416.

Yandell, Keith (2007) 'Who is the True Kant?' Philosophia Christi, 9, 81-97.

Cite this article: Kravitz, A. (2022). The Reason for Miracles and the Miracles in Reason: Kant's Practical Conception of Miracles. Kantian Review 27, 237-256. https://doi.org/10.1017/S1369415421000509 